\title{
Cytotoxicity assays to evaluate tannery effluents treated by photoelectrooxidation
}

\author{
N. Jaeger ${ }^{a}$, J. P. Moraes ${ }^{a}$, C. R. Klauck ${ }^{b}$, G. Gehlen ${ }^{b}$, M. A. S. Rodrigues ${ }^{b}$ and A. L. Ziulkoski ${ }^{a, b *}$ \\ áLaboratório de Citotoxicidade, Instituto de Ciências da Saúde, Universidade Feevale - FEEVALE, \\ ERS-239, 2755, CEP 93525-075, Novo Hamburgo, RS, Brazil \\ bPrograma de Pós-graduação em Qualidade Ambiental, Universidade Feevale - FEEVALE, \\ ERS-239, 2755, CEP 93525-075, Novo Hamburgo, RS, Brazil \\ *e-mail: analuiza@feevale.br
}

Received: January 17, 2015 - Accepted: May 20, 2015 - Distributed: November 30, 2015

(With 5 figures)

\begin{abstract}
The advanced oxidation process (AOP) is used to increase the treatment efficiency of effluents however, it is necessary to compare the toxicity of treated and untreated effluents to evaluate if the decontamination process does not cause any biological harm. Cultured cells have been previously used to assess the genotoxic and cytotoxic potential of various compounds. Hence, the aim of this work was to assess the applicability of cytotoxicity assays to evaluate the toxicity related to the AOP treatment. Samples of an industrial effluent were collected after their treatment by a conventional method. Cytotoxicity of standard and AOP treated effluents was assessed in CRIB and HEp-2 cell line using the MTT and neutral red assays. We observed decrease at cell viability in the both assays (50\% MTT and 13\% NRU) when cells were exposed to the AOP treatment in the highest concentration. Thus, cytotoxic assays in cultured cells can be explored as an useful method to evaluate toxicity as well as to optimize effluents treatment process.
\end{abstract}

Keywords: cytotoxicity, cell culture, effluent, photoelectrooxidation, tannery.

\section{Ensaios de citotoxicidade na avaliação de efluentes de curtume tratados por fotoeletrooxidação}

\section{Resumo}

O processo de oxidação avançada (POA) tem sido usado para aumentar a eficiência do tratamento de efluentes; no entanto, é necessário comparar a toxicidade de efluentes tratados e não tratados para avaliar se o processo de descontaminação não é capaz de causar algum risco biológico. Cultivos celulares têm sido utilizados para avaliar o potencial genotóxico e citotóxico de vários compostos. Assim, o objetivo deste trabalho foi avaliar a aplicabilidade de ensaios de citotoxicidade para avaliar a toxicidade relacionada ao tratamento com POA. As amostras de um efluente industrial foram recolhidas após o tratamento por um método convencional. A citotoxicidade dos efluentes padrão e tratado com POA foi avaliada nas linhagens celulares CRIB e HEp-2 usando os ensaios do MTT e do vermelho neutro. Observou-se diminuição da viabilidade celular em ambos os ensaios (50\% MTT e 13\% VN) quando as células foram expostas à concentração mais elevada do efluente tratado com POA. Assim, os ensaios de citotoxicidade em cultivos celulares podem ser explorados como um método útil para avaliar a toxicidade, bem como para otimizar os processos de tratamento de efluentes.

Palavras-chave: citotoxicidade, cultura de células, efluentes, fotoeletrooxidação, curtumes.

\section{Introduction}

Due to worldwide decline of water resources, treated wastewater now represents a growing portion of the water supply. Many surface water sources, such as rivers, lakes and reservoirs are used for both the disposal of treated wastewater and the withdrawal of fresh water for human consumption (Liu and Li, 2010). The presence of organic pollutants (Chen et al., 2000) and chemical pollution from heavy metals, solvents, dyes, pesticides, among others (Oller et al., 2011) in water and wastewater is one of the major threats to water quality as well as to human health and the environment.

Chemicals enter the aquatic medium in several different ways, either dumped directly, such as industrial effluents, or from wastewater treatment plants that do not fulfill their obligations (Oller et al., 2011). The correlation between industrial activity and environmental pollution has been extensively documented in recent decades (Melo et al., 2006). 
Among the various industrial sectors, the leather tannery industry is one of the leading economic sectors in many countries (Szpyrkowicz et al., 2001). Some of the agencies responsible for environmental management consider it as one of the 10 most harmful industrial effluents to the environment, responsible for extreme pollution of water resources since it generates substances, which leads to deterioration, and death of a wide range of organisms (Kumar et al., 2008). It is of great concern since it generates large quantities of heavily polluted wastewater because the transformation of the raw hide into leather requires different mechanical and chemical treatments (Singh and Rajamani, 2003). These effluents are greatly toxic; consequently they cannot be released into the environment without treatment (Bajza and Vrcek, 2001).

In the last years, after the enforcement of environmental legislation, tanneries started to treat the effluent water discharged from their productive processes. This effluent treatment normally consists of two stages: primary or physicochemical treatment and secondary or biological treatment. The conventional treatment used by the majority of Brazilian tanneries does not reestablish the original characteristics of normal feed water, so the effluent is unsuitable to be reused in the productive process. Many research reports have appeared on a special category of oxidation techniques called advanced oxidation process (AOP) (Sauer et al., 2006).

The AOP can promote the degradation of several pollutant complexes within a few minutes, including refractory composites that resist the conventional effluent treatment (Freire et al., 2000). Two different mechanisms can be identified for the oxidation of organics. Anodic oxidation can occur by the direct exchange between organic compounds and the surface of the electrode or indirectly through oxidant species formed at the anode (Faria et al., 1997; Simond et al., 1997; Chen, 2004). Oxidation occurs on active electrodes (electrodes which participate in the oxidation) due to the formation of a higher oxide. Several processes involving hydroxyl radical production have been studied, generally using ozone, hydrogen peroxide, ultrasound, photocatalysis with titanium dioxide, and reagent of Fenton's reagent (Cavicchioli and Gutz, 2001). The photoelectrooxidation process (PEO) consists of a combination of electrolysis and heterogeneous photocatalyses, using oxide-coated electrodes, such as $\mathrm{Ti} /\left(30 \mathrm{TiO}_{2}-70 \mathrm{RuO}_{2}\right)$. In this process, the only reagents involved are the photon and the electron (Rodrigues et al., 2008).

In order to evaluate the efficiency of the decontamination process, it is necessary to compare the toxicities of treated and untreated effluents. Toxicity tests are very important, especially when ozonation and photochemical processes are employed, since toxic compounds and reactive oxygen species might be generated during the treatment (Melo et al., 2006).

Bioassays (fish, invertebrates, cell cultures, bacterial or algae) have traditionally been used to assess the toxicity of effluents. Since not all forms of toxicity are detected in a single toxicity assay, different bioassays should be used to screen for a variety of effects. Cultured cells have been previously used to assess the genotoxic and mutagenic potential of various compounds (Filipic, 1995; Reifferscheid et al., 2008), including chemicals, medicines and effluents (Melo et al., 2006) since they are less expensive and can be performed more rapidly. Another advantage is the reduction in the use of whole animals in toxicity testing, manly for ethical reasons (Dayeh et al., 2005).

Therefore, the aim of this study was to assess the applicability of cytotoxicity assays not only to evaluate the toxicity related to the PEO treatment but also to provide toxicity data to optimize the treatment itself.

\section{Material and Methods}

\subsection{Effluents}

Effluent used in the study was collected at a discharge point in a conventional effluent treatment plant of a tannery located at Sinos valley (RS), which performs out all industrial processes from raw hides to finished leather, being the most of leather and, most of the leather was produced by chrome tanning. The analytical methods used followed the Standard Methods for the Examination of Water and Wastewater, 20th ed. (Clesceri et al., 1998).

\subsection{PEO experiments}

All oxidation experiments were conducted in the reactor schematically represented in Figure 1. The recirculation batch reactor system had an entrance in the inferior part and an exit in the superior part. In this system, the solution

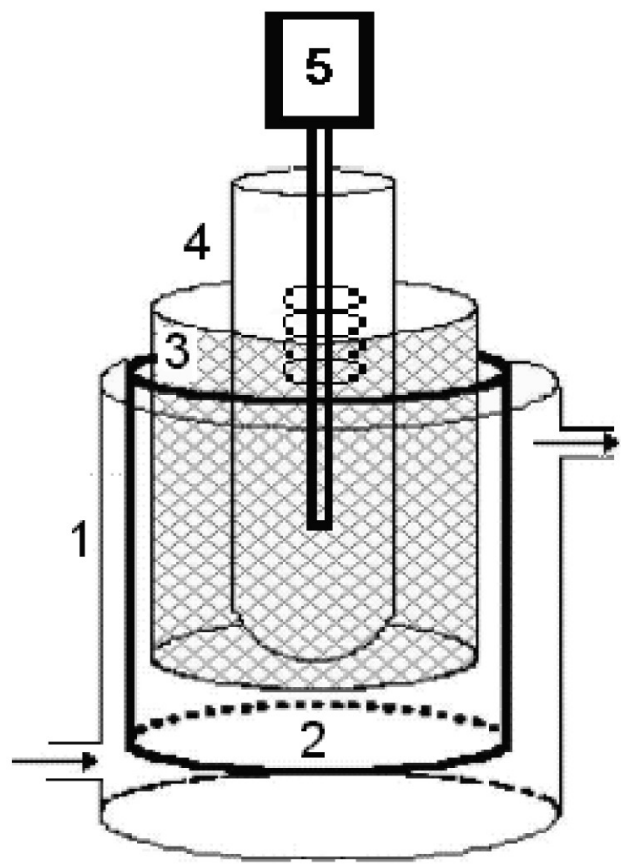

Figure 1. Photoreactor used in the PEO process. (1) glass reservoir with entrance and exit of effluent; (2) $\mathrm{Ti} / \mathrm{Ru}_{0,3} \mathrm{Ti}_{0,7} \mathrm{O}_{2}$ anode; (3) $\mathrm{Ti} / \mathrm{TiO}_{2}$ cathode; (4) quartz tube; (5) mercury-vapor lamp. 
to be treated was pumped into the reactor and returned to the tank for cooling. The glass bulb of the lamp was substituted by one tube of quartz, allowing the passage of UV radiation. A $400 \mathrm{~W}$ high-pressure mercury-vapor lamp was used as the light source. Before each experiment, the UV light was turned on for $15 \mathrm{~min}$ to allow the UV energy to become stable. The experiments were performed using a DC power supply. Two pairs of electrodes were used. The cathode and anode were DSA $\left(70 \mathrm{TiO}_{2} / 30 \mathrm{RuO}_{2}\right)$. Electrode area inside the cell was $118 \mathrm{~cm}^{2}$. During the experiments the reactor was operated in a batch recirculation mode. Effluent was recirculated at a flow rate of $4 \mathrm{~L} \mathrm{~h}^{-1}$ and $3 \mathrm{~L}$ of effluent was treated in each experiment. All degradation tests were 3 hours. Table 1 shows the values of monitored parameters from conventional treated tannery effluent and PEO treated effluent. PEO1, PEO2, PEO3 and PEO4 correspond to different electric current applied: 1, 2, 4 and 6 A, respectively.

\subsection{CRIB and HEp-2 cell culture}

Cytotoxicity of standard and PEO treated effluents, expressed as cell viability, was assessed in CRIB and HEp-2 cell line representative of bovine kidney and human laryngeal carcinoma epithelial cells, respectively. Cell lines were grown as monolayers in Dulbecco's modified Eagle's Medium (DMEM, Sigma ${ }^{\circledR}$ ), supplemented with $10 \%$ fetal bovine serum (FBS, Nutricell ${ }^{\circledR}$ ) and $0.1 \mathrm{mg} / \mathrm{mL}$ gentamicin $\left(\right.$ Schering-Plough $\left.{ }^{\circledR}\right)$ at $37{ }^{\circ} \mathrm{C}$ in a humidified incubator with $5 \% \mathrm{CO}_{2} / 95 \%$ air.

\subsection{Cell viability}

Samples of effluents were collected in sterilized recipients at each collecting time and immediately transported to the laboratory. The $\mathrm{pH}$ of effluents was adjusted to 7.0 and the solution was filtered using a $0.22 \mu \mathrm{m}$ membrane (Sartorius Biolab $\left.^{\circledR}\right)$, and stored in $45 \mathrm{~mL}$ falcons at $10^{\circ} \mathrm{C}$.

Cells were placed in 96-well plates at a density of $1 \times 10^{4}$ cells/ well in DMEM $10 \%$ FBS with gentamicin. The medium was removed $24 \mathrm{~h}$ after cell seeding and replaced with the medium (equal preparation of seeding medium) containing the effluents mixed in different dilutions (1:1 up to $1: 10,000, \mathrm{v}: \mathrm{v})$. Cells were exposed to a test medium with or without (control) effluents for $24 \mathrm{~h}$. In addition, cells were exposed to PBS in the same dilutions made for the effluents in order to test whether the dilution itself could causes viability lost. Each concentration was tested in six replicates and the assay was repeated twice in separate experiments. At the end of the incubation, two independent endpoints for cytotoxicity (MTT and NRU) were evaluated. Morphology of the cells was observed by an inverted microscope (Cal Zeiss ${ }^{\circledR}$ )

The tetrazolium reduction assay (MTT) was based as described by Mosmann (1983). Then, $0.2 \mathrm{~mL}$ of serum-free medium containing $0.05 \%$ 3-(4,5-dimethylthiazole- 2 -yl)2,5-biphenyl tetrazolium bromide (Sigma ${ }^{\circledR}$ ) was added to each well. After incubation for $2 \mathrm{~h}$, the culture medium was removed and $0.2 \mathrm{~mL}$ of DMSO (Nuclear ${ }^{\circledR}$ ) was added to each well to solubilize the formazan formed. The neutral red uptake (NRU) was measured by the method described by Borenfreund and Puerner (1987). After $3 \mathrm{~h}$ of incubation with serum-free medium containing $50 \mu \mathrm{g} / \mathrm{mL}$ of neutral red $\left(\right.$ Sigma $\left.{ }^{\circledR}\right)$, cells were washed twice with PBS and once with $0.2 \mathrm{~mL}$ of $1 \%$ calcium chloride in $0.5 \%$ phormaldeid solution to fix the cells. Finally, $0.2 \mathrm{~mL}$ of $1 \%$ acetic acid in $50 \%$ ethanol was added and plates were gently shaken for $10 \mathrm{~min}$ to solubilize the neutral red crystals. For both assays, the final solution was transferred to another 96 well plate and the absorbance was read at $540 \mathrm{~nm}$ in a microplate spectrophotometer (TR-Reader, ThermoPlate ${ }^{\circledR}$ ).

\subsection{Data analysis}

Statistical analysis was performed using one way-ANOVA and the differences were evaluated by Tukey post-test, using GraphPad Prism ${ }^{\circledR}$. A p $<0.05$ value was considered statistically significant.

\section{Results}

The results presented in Table 1 demonstrate that the effluent treated by conventional method (standard) does not reach the Brazilian Legal Standards for nitrogen compounds. Treatment with PEO is capable of degrading compounds present in the effluent. It is also observed that increasing the applied electric current provides an increase in removal of

Table 1. Characterization of treated effluent by conventional process and by PEO.

\begin{tabular}{ccccccc}
\hline Parameter & $\begin{array}{c}\text { Standard effluent } \\
\text { (Treated Conventional) }\end{array}$ & \multicolumn{3}{c}{ Treated Effluent (PEO) } & Legislation \\
\hline & & PEO1 & PEO2 & PEO3 & PEO4 \\
\hline $\mathrm{COD}\left(\mathrm{mgO}_{2} / \mathrm{L}\right)$ & 240 & 180 & 120.4 & 83.5 & 60.7 & $160-450$ \\
$\mathrm{BOD}_{5}\left(\mathrm{mgO}_{2} / \mathrm{L}\right)$ & 172 & 120.8 & 89.5 & 61 & 45.6 & $40-200$ \\
$\mathrm{pH}$ & 7.8 & 7.0 & 7.2 & 7.4 & 7.2 & $6.0-8.5$ \\
Total nitrogen $(\mathrm{mg} / \mathrm{L})$ & 243 & 201 & 106 & 89.7 & 20 & 10 \\
Ammoniacal nitrogen $(\mathrm{mg} / \mathrm{L})$ & 134 & 90 & 48.7 & 18.5 & 13.6 & 20 \\
Chlorides $(\mathrm{mg} / \mathrm{L})$ & 3990 & 3179 & 2801 & 1522 & 1232 & - \\
Phosphorus $(\mathrm{mg} / \mathrm{L})$ & 0.71 & 0.63 & 0.33 & 0.14 & 0.10 & 1.0 \\
Total chrome $(\mathrm{mg} / \mathrm{L})$ & 0.47 & 0,23 & $<0.005$ & $<0.005$ & $<0.005$ & 0.5 \\
Total calcium $(\mathrm{mg} / \mathrm{L})$ & 207 & 123 & 87 & 43 & 12 & - \\
Total magnesium $(\mathrm{mg} / \mathrm{L})$ & 212 & 152 & 64,8 & 30.8 & 18.3 & - \\
Electric current applied $(\mathrm{A})$ & - & 1 & 2 & 4 & 6 & - \\
\hline
\end{tabular}


all species present in the effluent. These results were also obtained by other authors, who treated textile effluents, humic acid, synthetic phenol solution, or bleach kraft mill effluents (Pelegrini et al., 1999; Neelavannan et al., 2007).

Two cell viability assays and cell lines were used to test the toxicity of the effluents. Figure $2 \mathrm{a}$ and $2 \mathrm{~b}$ show there was a significant difference between treatments in the MTT assay. Cell exposed to the lowest dilution of the effluent treated with PEO had a viability reduction comparing to cells exposed to effluent with the standard treatment: 95\% in CRIB and 48\% in HEp-2 cells (Figure $2 \mathrm{a}$ and $2 \mathrm{~b}$, respectively). Moreover, through microscopy evaluation it was possible to observe that cell detached from the well when exposed to PEO treatment while cells exposed to the standard treatment only formed vesicle in the cytoplasm, in the lowest dilution (data not shown).

Two different cell lines were used in order to evaluate if they would show different results due to their different phenotype. Fortunately, both cell lines showed the same pattern in this assay. Because of that, only one cell line (HEp-2) was chosen to perform the NRU assay (Figure 3). Similar results to the ones obtained from the MTT assay were observed to PEO treatment with only $20 \%$ of viability to the lowest dilution. However, MTT assay showed
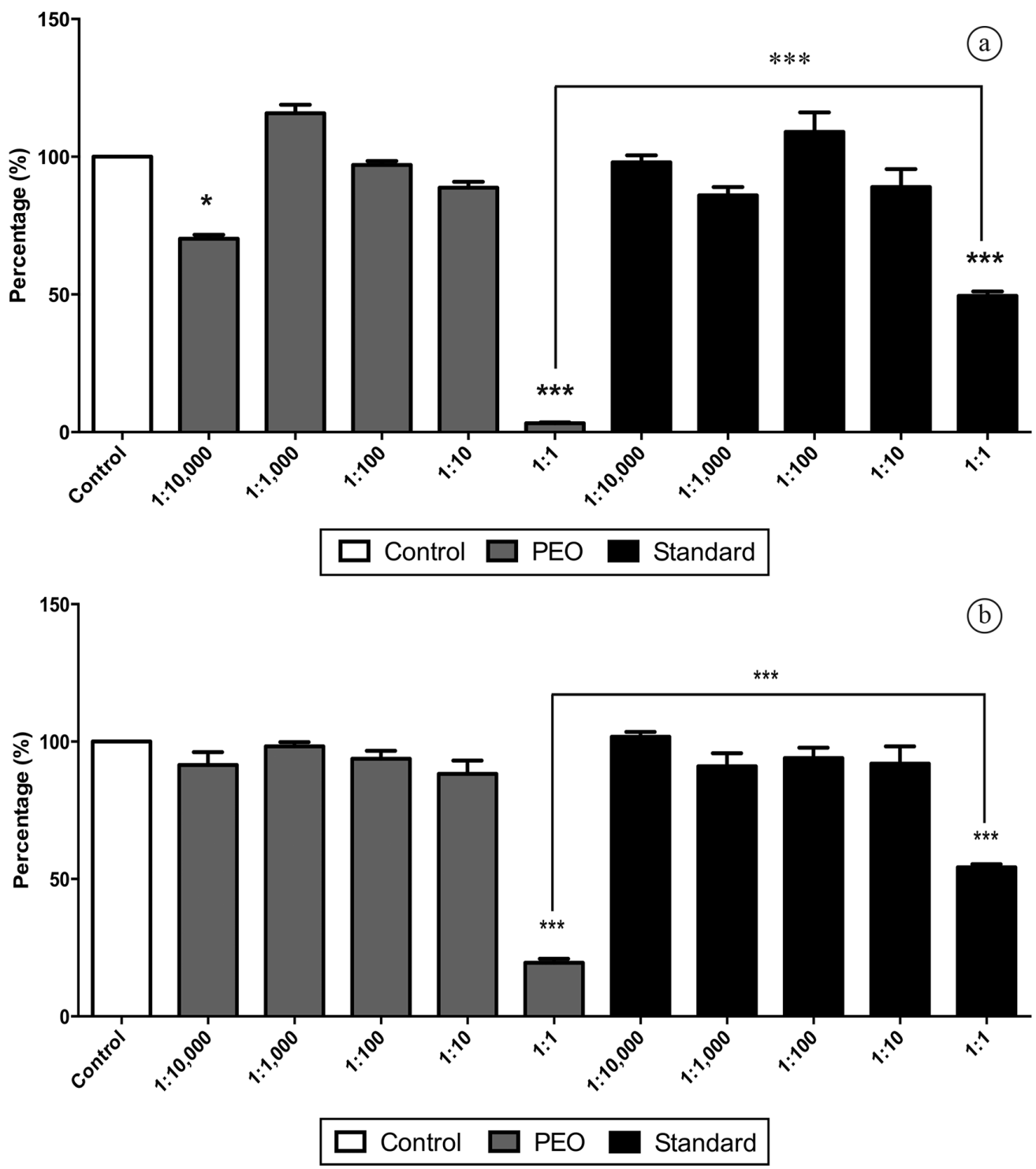

Figure 2. MTT assay in cell lines exposed to effluents. (a) CRIB cell line; (b) HEp-2 cell line. Evaluation of viability loss by MTT assay after exposure for 24 hours to standard and PEO effluent treatments. Values are expressed as the mean absorbance values \pm standard deviation of a representative experiment. The differences between the exposure doses were analyzed by one-way ANOVA and Tukey post-hoc test. Asterisks indicate results that were significantly different $(p<0.001)$ from each other. 
around $50 \%$ of cell viability decrease when exposed to the standard treatment while NRU showed a $13 \%$ decrease. The results found for the PEO treatment are similar in both cytotoxicity assays.
Cells exposed only to PBS showed no viability loss in any of the dilutions tested as well as no morphology alterations when compared to control in both MTT (Figures $4 \mathrm{a}$ and $4 \mathrm{~b}$ ) and NRU assays (Figure 4c).

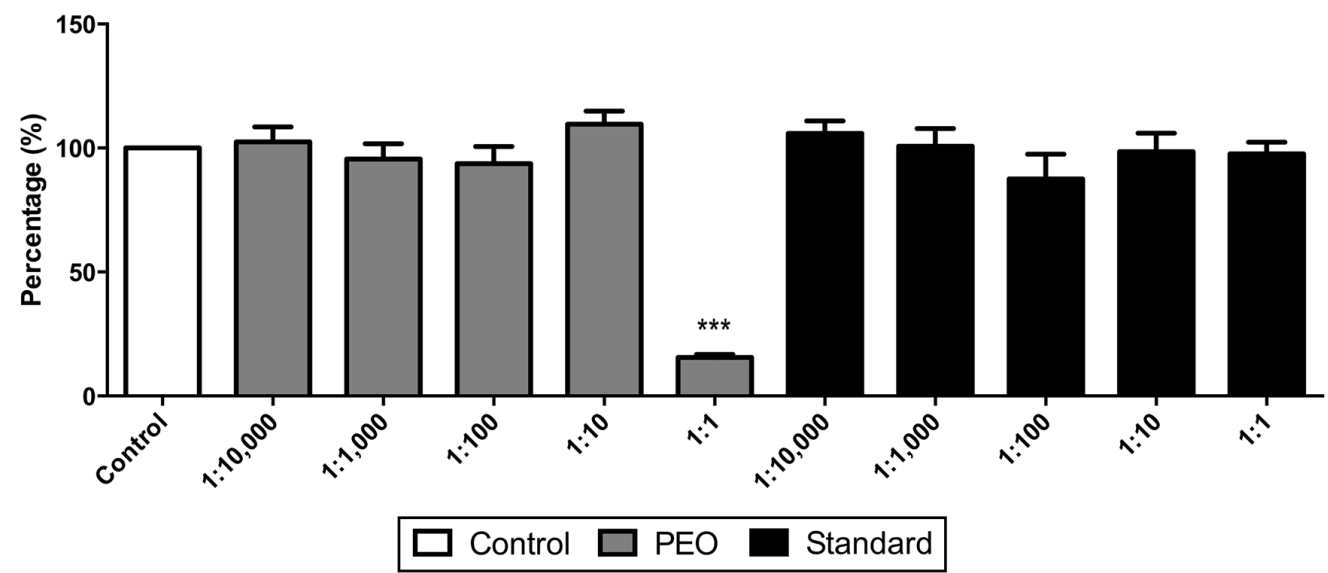

Figure 3. NRU assay of HEp-2 cell line exposed to standard and PEO effluent treatment. Evaluation of viability lost by NRU assay after exposure for 24 hours to standard and PEO effluent treatment on HEp-2 cell line. Values are expressed as the mean absorbance values \pm standard deviation of a representative experiment. The differences between the exposure doses were analyzed by one-way ANOVA and Tukey post-hoc test. Asterisks indicate results that were significantly different $(\mathrm{p}<0.001)$ from each other.
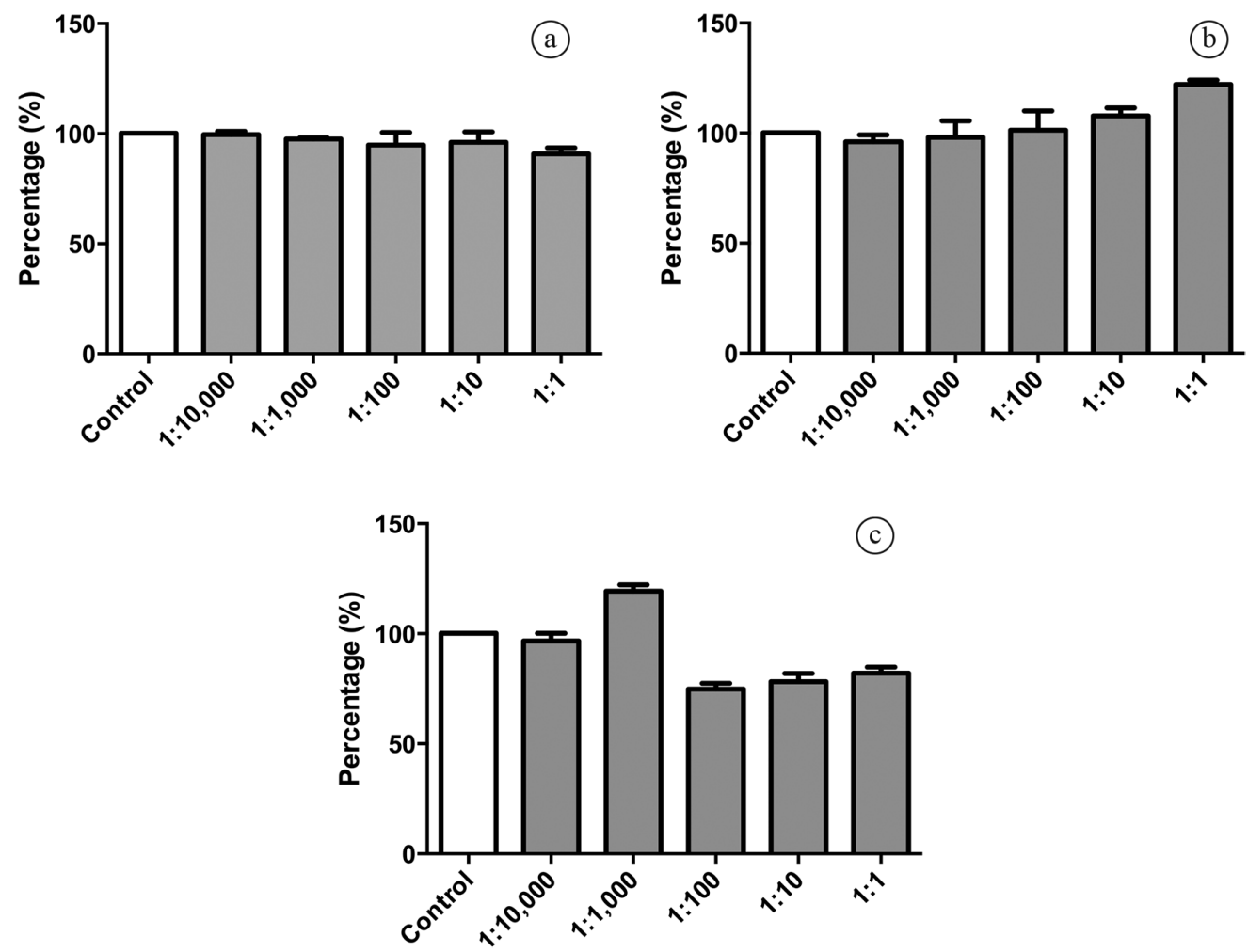

Figure 4. Cytotoxicity assay of cell lines exposed to PBS. (a) MTT assay of CRIB cell line; (b) MTT assay of HEp-2 cell line; (c) NRU assay of HEp-2 cell line. Evaluation of viability loss of cell lines by cytotoxicity assays after exposure for 24 hours to PBS. Values are expressed as the mean absorbance values \pm standard deviation of a representative experiment. The differences between the exposure doses were analyzed by one-way ANOVA and Tukey post-hoc test. 


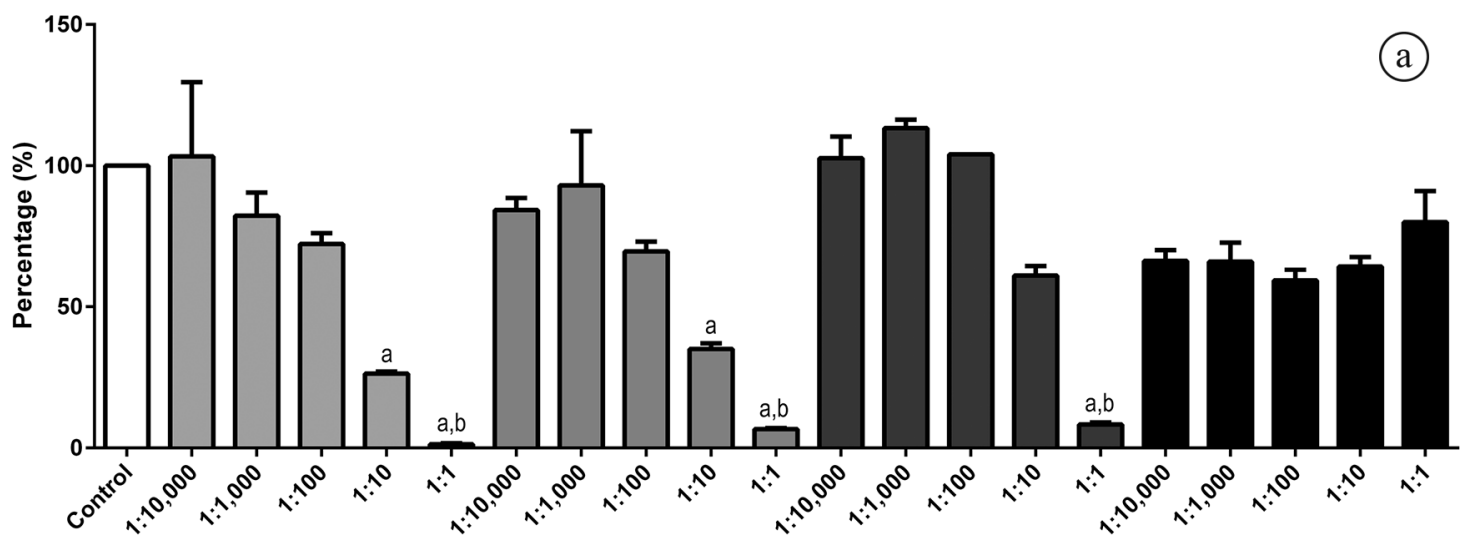

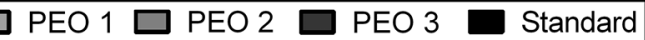

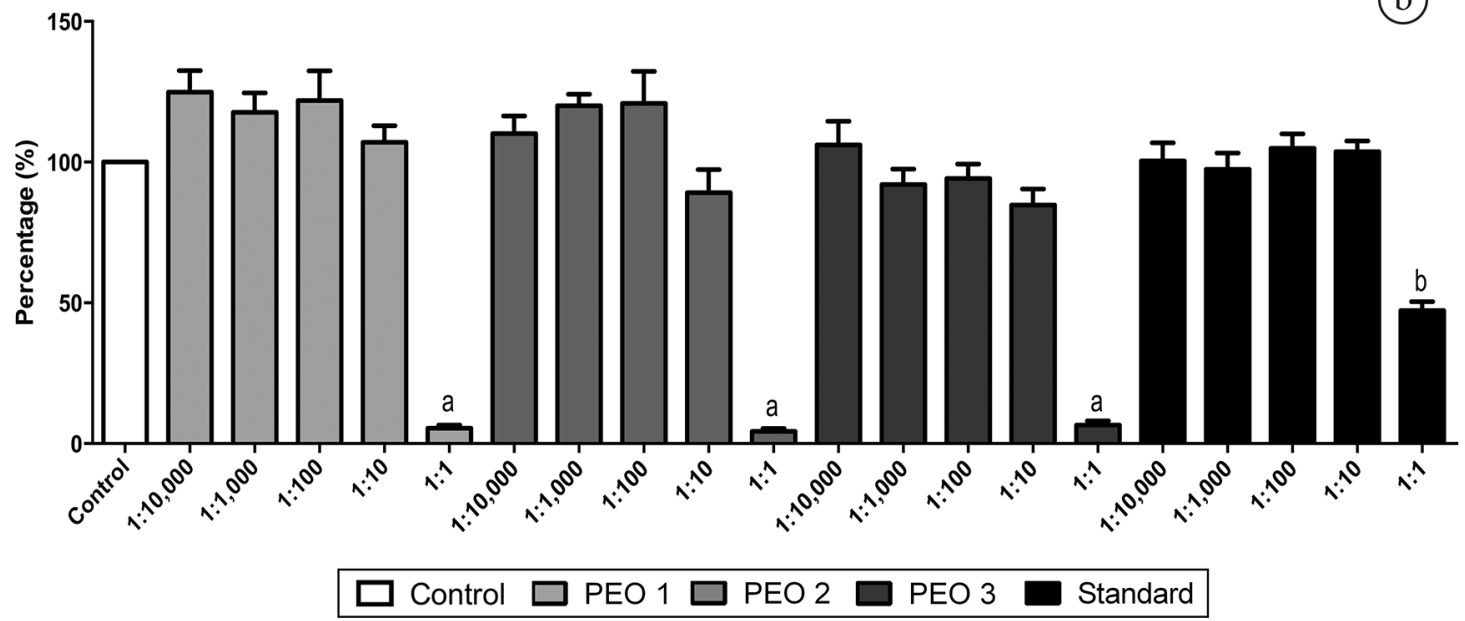

Figure 5. MTT assay of cell lines exposed to standard and three different electric conditions of PEO effluent treatment. (a) CRIB cell line; (b) HEp-2 cell line. Evaluation of viability loss of cell lines by MTT assay after exposure for 24 hours to standard and three different periods of PEO effluent treatment. Values are expressed as the mean absorbance values \pm standard deviation of a representative experiment. The differences between the exposure doses were analyzed by one-way ANOVA and Tukey post-hoc test. Letters indicate results that were significantly different $(\mathrm{p}<0.001)$.

The effect the PEO treatment was also tested when collected in different electric conditions (PEO1, PEO2 and PEO3) of the treatment process (Figure 5a and 5b). Similar results to the previous MTT were found $(95 \%$ of reduction in viability) and also, a slight tendency, not significant though to decrease viability loss (around 5\% less) in CRIB cells exposed to the final sample of the treatment was observed. As previously, both cell lines presented the same pattern for the MTT assay.

\section{Discussion}

In this study, we show that the MTT and NRU assays on different cell line are efficient in vitro alternatives to assess the citotoxicity of effluents. Viability loss was observed in both assays when cells were exposed to the PEO treatment of tannery effluents. The leather tannery industry produces greatly toxic effluents that cannot be released into the environment without treatment (Bajza and Vrcek, 2001). Recently, advanced oxidation processes have been developed as an alternative to the conventional treatment (Sauer et al., 2006). However, these processes use different reaction systems producing hydroxyl radicals $\left(\mathrm{OH}^{\circ}\right)$ which has high oxidative power and can produce by-products which may modify the toxic and mutagenic properties of effluents (Petala et al., 2008). Furthermore, it is known that chemical analysis of complex mixtures offers limited information about their real toxicity since different reactions can be occurring in the mixture like synergistic effects and interactions during and following discharge (Donnelly et al., 2004).

Several in vitro bioassays for the determination of cytotoxic and genotoxic potential of wastewater samples has been proposed using prokaryotic organism, like the Ames test or the SOS chromotest (Zegura et al., 2009). However, these bioassays are not able to assess all the 
possible effects on eukaryotic organisms. MTT and NRU assays can been used to assess cytotoxicity in vitro since they evaluate different aspects of cellular functions and, therefore, can be useful to examine the potential hazardous effects of effluents treatment. The reduction of MTT evaluates the functional intactness of mitochondria based on the enzymatic reduction of a tetrazolium salt by the mitochondrial dehydrogenase of viable cells (Mosmann, 1983). NRU is a measure of lysosomal integrity since it reflects the capacity of viable cells to incorporate vital dye into these organelles (Borenfreund and Puerner, 1987).

The AOPs degrade organic pollutants, thus they produce free radical of oxygen species that react with hydrogen peroxide and form hydroxyl radical. The production of hydroxyl radicals damages all components of the cell such as: proteins, DNA and lipid membranes; which compromises cell integrity and interrupts its functions (Kadiiska et al., 1994; Patlolla et al., 2009). Hence, the viability loss seen on cells exposed to the PEO treatment could be due to the toxic effects caused by the hydroxyl radicals formed during the degradation of organic pollutants present in these effluents samples. Similar results were found by other researches such as Yuan et al. (2005), who exposed HepG2 cells to drinking water after chlorination treatment and observed an increased formation of malondialdehyde (MDA) showing that the treatment caused the formation of oxygen-derived free radicals, which led to oxidative stress and consequently cell damage.

Similar to other studies (Weyermann et al., 2005; Wang et al., 2010), different results were found in the cytotoxic assays performed. MTT showed a higher cell viability loss when cells were exposed to the standard treatment when compared to the NRU assay. Since the reduction of the tretazolium salt takes place only when mitochondrial reductase enzymes are active, this assay has some limitations influenced by the physiological state of cells and variance in mitochondrial dehydrogenase activity in different cell types. It is also important to consider that if the substances present in the effluent cause too much damage to the cell and consequently to its mitochondrias, the cell can undergo apoptosis. Hence, the higher viability loss seen in the MTT assay could be explained by the mitochondrial damaged that is detected by $\mathrm{Bcl}-2$ proteins, which leads to programmed cell death mediated by caspase- 9 (Adams, 2003; Marsden et al., 2004).

We also analyzed if the cytotoxic assays could identify alterations or the reduction of cell potential damage in different experimental conditions of the effluent treatment by PEO. We observed that cells exposed to sample collected in PEO3 treatment had a smaller percentage of viability loss than cells exposed to PEO1 and PEO2 treatment. Even though this difference was not statistically significant, it can be useful to optimize the treatment since it indicates that some component present in the PEO is degraded along the process making the effluent less cytotoxic.

Numerous in vitro assays have been developed as alternatives of toxicity tests in vivo. In vitro tests are generally rapid, sensitive, amenable to automation, economic and less controversial compared to the use of whole animals (Butler, 2004). However, only recently researchers have started to utilize cell cultures in order to evaluate effluents toxicity. There are still a few studies in the literature but some examples are Shi et al. (2009) who used HepG2 cell line and MTT assay to evaluate the toxicity of surface water disinfected by different treatments and Llorente et al. (2012) who used rainbow trout cells to test the cytotoxicity and genotoxicity of sewage treatment plants effluents.

With this study we also concluded that cytotoxicity assays should be an integral tool in the evaluation of toxicity of effluents treatments before the release into the environment. Therefore, cell culture together with cytotoxic assays could be a useful method to evaluate toxicity as well as to optimize effluents treatment.

\section{Acknowledgements}

The authors thank the grant support from the Conselho Nacional de Desenvolvimento Científico e Tecnológico (CNPq) Grant 477784/2011-9.

\section{References}

ADAMS, J.M., 2003. Ways of dying: multiple pathways to apoptosis. Genes \& Development, vol. 17, no. 20, pp. 2481-2495. http://dx.doi.org/10.1101/gad.1126903. PMid:14561771.

BAJZA, Z. and VRCEK, I.V., 2001. Water quality analysis of mixtures obtained from tannery waste effluents. Ecotoxicology and Environmental Safety, vol. 50, no. 1, pp. 15-18. http://dx.doi. org/10.1006/eesa.2001.2085. PMid:11534948.

BORENFREUND, E. and PUERNER, J.A., 1987. Short-term quantitative in vitro cytotoxicity assay involving an S-9 activating system. Cancer Letters, vol. 34, no. 3, pp. 243-248. http://dx.doi. org/10.1016/0304-3835(87)90173-X. PMid:3828978.

BUTLER, M., 2004. Animal cell culture and technology. New York: Taylor \& Francis. The Basics.

CAVICCHIOLI, A. and GUTZ, I.G.R., 2001. In-line $\mathrm{TiO}_{2}-$ assisted photodigestion of organic matter in aqueous solution for voltammetric flow analysis of heavy metals in water samples. Analytica Chimica Acta, vol. 445, no. 2, pp. 127-138. http:// dx.doi.org/10.1016/S0003-2670(01)01258-2.

CHEN, G., 2004. Electrochemical technologies in wastewater treatment. Separation and Purification Technology, vol. 38, no. 1, pp. 11-41. http://dx.doi.org/10.1016/j.seppur.2003.10.006.

CHEN, P.H., LEUNG, K.C. and WANG, J.T., 2000. Investigation of a ponding irrigation system to recycle agricultural wastewater. Environment International, vol. 26, no. 1-2, pp. 63-68. http:// dx.doi.org/10.1016/S0160-4120(00)00079-9. PMid:11345740.

CLESCERI, L.S., GREENBERG, A.E. and EATON, A.D., 1998. Standard methods for the examination of water and wastewater. 20th ed. Washington: American Public Health Association.

DAYEH, V.R., LYNN, D.H. and BOLS, N.C., 2005. Cytotoxicity of metals common in mining effluent to rainbow trout cell lines and to the ciliated protozoan, Tetrahymena thermophila. Toxicology In Vitro, vol. 19, no. 3, pp. 399-410. http://dx.doi.org/10.1016/j. tiv.2004.12.001. PMid:15713547. 
DONNELLY, K.C., LINGENFELTER, R., CIZMAS, L., FALAHATPISHEH, M.H., QIAN, Y., TANG, Y., GARCIA, S., RAMOS, K., TIFFANY-CASTIGLIONI, E. and MUMTAZ, M.M., 2004. Toxicity assessment of complex mixtures remains a goal. Environmental Toxicology and Pharmacology, vol. 18, no. 2, pp. 135-141. http://dx.doi.org/10.1016/j.etap.2004.03.013. PMid:21782742

FARIA, L.A., BOODTS, J.F.C. and TRASATTI, S., 1997. Electrocatalytic properties of $\mathrm{Ru}+\mathrm{Ti}+\mathrm{Ce}$ mixed oxide electrodes for the $\mathrm{Cl}_{2}$ evolution reaction. Electrochimica Acta, vol. 42, no. 23-24, pp. 3525-3530. http://dx.doi.org/10.1016/S00134686(97)00029-7.

FILIPIC, M., 1995. Mutagenicity and toxicity of water extracts from the Sora river area. Mutation Research, vol. 342, no. 1-2, pp. 1-8. http://dx.doi.org/10.1016/0165-1218(95)90084-5. PMid:7885390.

FREIRE, R.S., PELEGRINI, R., KUBOTA, L.T., DURAN, N. and PERALTA-ZAMORA, P., 2000. Novas tendências para o tratamento de resíduos industriais contendo espécies organocloradas. Quimica Nova, vol. 23, no. 4, pp. 504-511. http://dx.doi.org/10.1590/ S0100-40422000000400013.

KADIISKA, M.B., XIANG, Q.H. and MASON, R.P., 1994. In vivo free radical generation by chromium(VI): an electron spin resonance spin-trapping investigation. Chemical Research in Toxicology, vol. 7, no. 6, pp. 800-805. http://dx.doi.org/10.1021/ tx00042a013. PMid:7696535.

KUMAR, V., MAJUMDAR, C. and ROY, P., 2008. Effects of endocrine disrupting chemicals from leather industry effluents on male reproductive system. The Journal of Steroid Biochemistry and Molecular Biology, vol. 111, no. 3-5, pp. 208-216. http:// dx.doi.org/10.1016/j.jsbmb.2008.06.005. PMid:18606229.

LIU, J.L. and LI, X.Y., 2010. Biodegradation and biotransformation of wastewater organics as precursors of disinfection byproducts in water. Chemosphere, vol. 81, no. 9, pp. 1075-1083. http:// dx.doi.org/10.1016/j.chemosphere.2010.09.041. PMid:20943251.

LLORENTE, M.T., PARRA, J.M., SÁNCHEZ-FORTÚN, S. and CASTAÑO, A., 2012. Cytotoxicity and genotoxicity of sewage treatment plant effluents in rainbow trout cells (RTG-2). Water Retos, vol. 46, no. 19, pp. 6351-6358. http://dx.doi.org/10.1016/j. watres.2012.08.039. PMid:23022116.

MARSDEN, V.S., EKERT, P.G., VAN DELFT, M., VAUX, D.L., ADAMS, J.M. and STRASSER, A., 2004. Bcl-2-regulated apoptosis and cytochrome c release can occur independently of both caspase-2 and caspase-9. The Journal of Cell Biology, vol. 165, no. 6, pp. 775-780. http://dx.doi.org/10.1083/jcb.200312030. PMid:15210727.

MELO, P.S., FABRIN-NETO, J.B., DE MORAES, S.G., ASSALIN, M.R., DURAN, N. and HAUN, M., 2006. Comparative toxicity of effluents processed by different treatments in V79 fibroblasts and the algae Selenastrum capricornutum. Chemosphere, vol. 62, no. 8, pp. 1207-1213. http://dx.doi.org/10.1016/j.chemosphere.2005.01.081. PMid:16337671

MOSMANN, T., 1983. Rapid colorimetric assay for cellular growth and survival: application to proliferation and cytotoxicity assays. Journal of Immunological Methods, vol. 65, no. 1-2, pp. 55-63. http://dx.doi.org/10.1016/0022-1759(83)90303-4. PMid:6606682.

NEELAVANNAN, M.G., REVATHI, M. and AHMED BASHA, C., 2007. Photocatalytic and electrochemical combined treatment of textile wash water. Journal of Hazardous Materials, vol. 149, no. 2, pp. 371-378. http://dx.doi.org/10.1016/j.jhazmat.2007.04.025. PMid:17509754.
OLLER, I., MALATO, S. and SANCHEZ-PEREZ, J.A., 2011. Combination of advanced oxidation processes and biological treatments for wastewater decontamination--a review. The Science of the Total Environment, vol. 409, no. 20, pp. 4141-4166. http:// dx.doi.org/10.1016/j.scitotenv.2010.08.061. PMid:20956012.

PATLOLLA, A.K., BARNES, C., HACKETT, D. and TCHOUNWOU, P.B., 2009. Potassium dichromate induced cytotoxicity, genotoxicity and oxidative stress in human liver carcinoma (HepG2) cells. International Journal of Environmental Research and Public Health, vol. 6, no. 2, pp. 643-653. http://dx.doi.org/10.3390/ ijerph6020643. PMid:19440407.

PELEGRINI, R., PERALTA-ZAMORA, P., DE ANDRADE, A.R., REYES, J. and DURÁN, N., 1999. Electrochemically assisted photocatalytic degradation of reactive dyes. Applied Catalysis B: Environmental, vol. 22, no. 2, pp. 83-90. http://dx.doi.org/10.1016/ S0926-3373(99)00037-5.

PETALA, M., SAMARAS, P., ZOUBOULIS, A., KUNGOLOS, A. and SAKELLAROPOULOS, G.P., 2008. Influence of ozonation on the in vitro mutagenic and toxic potential of secondary effluents. Water Research, vol. 42, no. 20, pp. 4929-4940. http://dx.doi. org/10.1016/j.watres.2008.09.018. PMid:18930304

REIFFERSCHEID, G., ZIEMANN, C., FIEBLINGER, D., DILL, F., GMINSKI, R., GRUMMT, H.J., HAFNER, C., HOLLERT, H., KUNZ, S., RODRIGO, G., STOPPER, H. and SELKE, D., 2008. Measurement of genotoxicity in wastewater samples with the in vitro micronucleus test: results of a round-robin study in the context of standardisation according to ISO. Mutation Research, vol. 649, no. 1-2, pp. 15-27. http://dx.doi.org/10.1016/j. mrgentox.2007.07.015. PMid:17980648

RODRIGUES, M.A.S., AMADO, F.D.R., XAVIER, J.L.N., STREIT, K.F., BERNARDES, A.M. and FERREIRA, J.Z., 2008. Application of photoelectrochemical-electrodialysis treatment for the recovery and reuse of water from tannery effluents. Journal of Cleaner Production, vol. 16, no. 5, pp. 605-611. http://dx.doi. org/10.1016/j.jclepro.2007.02.002.

SAUER, T.P., CASARIL, L., OBERZINER, A.L., JOSE, H.J. and MOREIRA, R.F., 2006. Advanced oxidation processes applied to tannery wastewater containing Direct Black 38--elimination and degradation kinetics. Journal of Hazardous Materials, vol. 135, no. 1-3, pp. 274-279. http://dx.doi.org/10.1016/j.jhazmat.2005.11.063. PMid:16387434.

SHI, Y., CAO, X.W., TANG, F., DU, H.R., WANG, Y.Z., QIU, X.Q., YU, H.P. and LU, B., 2009. In vitro toxicity of surface water disinfected by different sequential treatments. Water Research, vol. 43, no. 1, pp. 218-228. http://dx.doi.org/10.1016/j. watres.2008.10.007. PMid:18977503.

SIMOND, O., SCHALLER, V. and COMNINELLIS, C., 1997. Theoretical model for the anodic oxidation of organics on metal oxide electrodes. Electrochimica Acta, vol. 42, no. 13-14, pp. 2009-2012. http://dx.doi.org/10.1016/S0013-4686(97)85475-8.

SINGH, S. and RAJAMANI, S., 2003. Issues of environmental compliance in developing countries. Water Science and Technology, vol. 47 , no. 12 , pp. 301-304. PMid:12926702

SZPYRKOWICZ, L.H., KELSALL, G.N., KAUL, S. and DE FAVERI, M., 2001. Performance of electrochemical reactor for treatment of tannery wastewaters. Chemical Engineering Science, vol. 56, pp. 1579-1586. http://dx.doi.org/10.1016/ S0009-2509(00)00385-7.

WANG, P., HENNING, S.M. and HEBER, D., 2010. Limitations of MTT and MTS-based assays for measurement of antiproliferative 
activity of green tea polyphenols. PLoS One, vol. 5, no. 4, pp. e10202. http://dx.doi.org/10.1371/journal.pone.0010202. PMid:20419137.

WEYERMANN, J., LOCHMANN, D. and ZIMMER, A., 2005. A practical note on the use of cytotoxicity assays. International Journal of Pharmaceutics, vol. 288, no. 2, pp. 369-376. http:// dx.doi.org/10.1016/j.ijpharm.2004.09.018. PMid:15620877.

YUAN, J., WU, X.J., LU, W.Q., CHENG, X.L., CHEN, D., LI, X.Y., LIU, A.L., WU, J.J., XIE, H., STAHL, T. and MERSCHSUNDERMANN, V., 2005. Chlorinated river and lake water extract caused oxidative damage, DNA migration and cytotoxicity in human cells. International Journal of Hygiene and Environmental Health, vol. 208, no. 6, pp. 481-488. http://dx.doi.org/10.1016/j. ijheh.2005.09.002. PMid:16325558.

ZEGURA, B., HEATH, E., CERNOSA, A. and FILIPIC, M., 2009. Combination of in vitro bioassays for the determination of cytotoxic and genotoxic potential of wastewater, surface water and drinking water samples. Chemosphere, vol. 75, no. 11, pp. 1453-1460. http://dx.doi.org/10.1016/j.chemosphere.2009.02.041. PMid:19307011. 